\title{
Solvent extraction with DP-8R/LIX 860 mixtures for the selective separation of cobalt and nickel( ${ }^{(\cdot)}$
}

\author{
F.J. Alguacil ${ }^{*}$
}

\begin{abstract}
DP-8R and LIX 860 extractans diluted with Exxsol D100 was used to co-extract cobalt and nickel from sulphate aqueous media. The influence of equilibration time, temperature, equilibrium $\mathrm{pH}$ and extractants mixture concentration on the extraction of both metals has been studied. It was observed that neither cobalt nor nickel extraction is sensitive to temperature, reaching in both cases the extraction equilibrium within 5 min of contact; however nickel is extracted preferably to cobalt at slightly acidic $\mathrm{pH}$ values and also using various extractants mixture concentrations. For a solution containing $1 \mathrm{~g} / \mathrm{l}$ each of cobalt and nickel and initial $\mathrm{pH}$ value of 5.5, conditions were established for the co-extraction of both metals and selective stripping (with $\mathrm{H}_{2} \mathrm{SO}_{4}$ ) of cobalt and nickel. Using the appropriate extractants concentrations the yield (extraction stage) for both metals is near $90 \%$, whereas the percentage of cobalt and nickel stripping is almost also quantitative.
\end{abstract}

Keywords

DP-8R. LIX 860. Co-extraction. Selective stripping. Cobalt. Nickel

\section{Separación selectiva de cobalto y níquel mediante extracción con mezclas de DP-8R y LIX 860}

Resumen

Palabras clave
Los agentes de extracción DP-8R y LIX 860 diluidos en Exxsol D100 se han empleado para la co-extracción de cobalto y níquel en medio sulfato. Se estudia la influencia del tiempo de equilibrado, la temperatura, el $\mathrm{pH}$ de equilibrio y la concentración de la mezcla de agentes de extracción sobre la extracción de ambos metales. La extracción de cobalto y níquel no depende de la temperatura, alcanzándose en ambos casos el equilibrio de extracción a los 5 min de contacto; el níquel se extrae preferentemente al cobalto a valores de pH más ácidos y, también, empleando distintas concentraciones de la mezcla de los agentes de extracción. Para una solución, conteniendo $1 \mathrm{~g} / \mathrm{l}$ de cada uno de los dos metales y un $\mathrm{pH}$ inicial de 5,5, se han establecido las condiciones para la co-extracción de ambos metales y la reextracción selectiva (con $\mathrm{H}_{2} \mathrm{SO}_{4}$ ) del cobalto y el níquel. Empleando las concentraciones de los agentes de extracción apropiadas, el rendimiento (en la etapa de extracción) para los dos metales es casi del $90 \%$, mientras que el tanto por ciento de reextracción de cobalto y níquel también es casi cuantitativo.

DP-8R. LIX 860. Co-extracción. Reextracción selectiva. Cobalto. Níquel

\section{INTRODUCTION}

Production of cobalt and nickel is carrying out from the hydrometallurgical treatment of various resources: raw materials (oxidic and sulphide ores) and secondary materials (sludges, spent catalysts, etc.). The leaching of such resources leads to obtain cobalt(II)/nickel(II) bearing solutions in which other impurities can also be found.
The separation of cobalt(II) and nickel(II) from these aqueous solutions is not an easy task due to their similar physical and chemical properties, various approaches have been used over the last two decades, including solvent extraction especially with acidic organophosporous derivatives ${ }^{[1-5]}$.

Though the cobalt/nickel separation from high chloride medium using amines or by these acidic organophosphorous derivatives from weakly acidic

(•) Trabajo recibido el día 3 de Diciembre de 2001 y aceptado en su forma final el día 8 de Marzo de 2002.

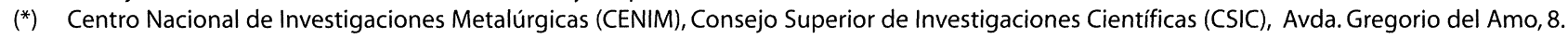
28040 Madrid (España). 
or neutral solutions have been of commercial use in past years ${ }^{[6]}$, the separation of both metals from more acidic sulphate media, i.e. $\mathrm{pH}$ below 3 , is not a resolved problem ${ }^{[7]}$. One approach to enhance the extraction of cobalt(II) and nickel(II) from these acidic solutions is by the use of mixtures of extractants, thus obtaining a synergistic effect. In the synergistic solvent extraction of metal ions or complexes, a mixture of (normally) two extractants is found to extract more strongly that would be expected from the sum of the extraction coefficients found by the separate extractants ${ }^{[8]}$. Various extractants mixtures had been used to improve the extraction/separation of different metals ${ }^{[9-11]}$ and just recently the use of a mixture of di(2-ethylhexyl)phosphoric acid and 5dodecylsalicylaldoxime reagents in the coextraction of both nickel and cobalt from acidic $\mathrm{pH}$ solutions had been reported in the literature ${ }^{[12]}$.

On the other hand, processing using solvent extraction for the separation of various metals can be performed using two alternatives: selective extraction or co-extraction and selective stripping, often the latter processing option is more economical as it requires fewer stages.

Due to the foremost importance that this topic has in the modern Hydrometallurgy, the present work presents complementary data on the coextraction of cobalt(II) and nickel(II) from acidic sulphate solutions using the reagents mixture of DP-8R (phosphoric acid) and LIX 860 (salicylaldoxime), and their separation by selective stripping.

\section{EXPERIMENTAL PART}

Cobalt(II) and nickel(II) solutions were prepared by dissolving the corresponding sulphate salts in distilled water.

The commercial extractants DP-8R (Daihachi) and LIX 860 (Cognis) were used as received. The active substance of DP-8R being bis(2ethylhexyl)phosphoric acid, whereas oximes of salicyl aldehide alkyl derivatives, such as LIX 860, belonging to the fourth group of oxime derivatives and form the second generation of hydroxyoxime derivatives ${ }^{[13]}$. The active substance of LIX 860 being 5-dodecylsalicylaldoxime. Exxon D100 was supplied by ExxonMobil Chem. Iberia (Spain) and used as obtained; its characteristics are: boiling range 239-265 (C, flash point 102 (C) aromatic components $0.2 \%$, density $0.819 \mathrm{~g} / \mathrm{cm}^{3}$ (15 (C). All other chemicals were of AR grade.
Solvent extraction experiments were carried out, under the corresponding experimental conditions, in separatory funnels thermostatted at the required temperature and mechanically shaken $\left(700 \mathrm{~min}^{-1}\right)$. Metal concentrations were determined by AAS using a Perkin Elmer 1100B spectrophotometer.

The accuracy of the metal mass balance was checked by complete stripping of the loaded organic solution with $180 \mathrm{~g} / \mathrm{l}$ sulphuric acid solution and analysis of the strip raffinates. Comparison of analytical results with those obtained by mass balance showed an overall accuracy of $98 \%$.

\section{RESULTS AND DISCUSSION}

In acidic aqueous sulphate media the extraction of cobalt(II) and nickel(II) using mixtures of acidic reagents such as DP-8R $\left(\mathrm{H}_{2} \mathrm{~L}_{2}\right)$ and LIX 860 (HR) is based on the following and general cationic exchange reaction:

$$
\begin{aligned}
& \mathrm{M}_{a q}^{2+}+p\left(\mathrm{H}_{2} L_{2}\right)_{\text {org }}+q \mathrm{HR}_{\text {org }} \rightleftarrows \\
& \rightleftarrows \mathrm{M}\left(\mathrm{L}_{2 p} \mathrm{R}_{q} \mathrm{H}_{2 p+q-2}\right)_{\text {org }}+2 \mathrm{H}_{a q}^{+}
\end{aligned}
$$

being:

$$
K_{\text {ext }}=\frac{\left[\mathrm{M}\left(\mathrm{L}_{2 p} \mathrm{R}_{q} \mathrm{H}_{2 p+q-2}\right)\right]_{\text {org }}\left[\mathrm{H}^{+}\right]_{a q}^{2}}{\left[\mathrm{M}^{2+}\right]_{a q}\left[\mathrm{H}_{2} \mathrm{~L}_{2}\right]_{\text {org }}^{p}[\mathrm{HR}]_{\text {org }}^{q}}
$$

However, the oxime reagent is amenable to dimerize (HR $)_{2}^{[13]}$, and the stoichiometry of the extracted species then can be represented as $\mathrm{M}\left(\mathrm{L}_{4} \mathrm{R}_{4} \mathrm{H}_{4}\right)$ in the case of $\mathrm{p}=\mathrm{q}=2$ (eq.(1)). It can also be pointed out that in the case of nickel $\mathrm{p}=2$ to 4 depending on the extractant concentration $^{[14,15]}$.

The metal distribution coefficient $\left(D_{M}\right)$ is defined by:

$$
D_{\mathrm{M}}=\frac{\left[\mathrm{M}^{2+}\right]_{o r g}}{\left[\mathrm{M}^{2+}\right]_{a q}}
$$

where $\left[\mathrm{M}^{2+}\right]_{\text {org }}$ and $\left[\mathrm{M}^{2+}\right]_{\mathrm{aq}}$ represented the total analytical metal concentrations at equilibrium in the respective organic and aqueous phases. By substitution of eq.(3) into eq.(2) and after rearranging, the next expression is obtained:

$$
\begin{aligned}
\log D_{M} & =\log K_{\text {ext }}+p \log \left[\mathrm{H}_{2} \mathrm{~L}_{2}\right]_{\text {org }}+ \\
& +q \log [\mathrm{HR}]_{\text {org }}+2 p \mathrm{H}
\end{aligned}
$$




\subsection{Influence of equilibration time and equilibrium $\mathrm{pH}$}

Experiments were performed to study the influence of the equilibration time and the equilibrium $\mathrm{pH}$ on the extraction of cobalt(II) and nickel(II) by the mixture DP-8R and LIX 860. In both cases, the aqueous solutions contained $1 \mathrm{~g} / \mathrm{l}$ of nickel or cobalt and the organic solutions were of $20 \% \mathrm{v} / \mathrm{v}$ DP-8R and $20 \% \mathrm{v} / \mathrm{v}$ LIX 860 in Exxsol D100. Other experimental variables and results obtained from this set of experiments were summarized in table I. From experimental results, a plot of $\log D_{M}$ versus $\mathrm{pH}_{\mathrm{eq}}$ (Fig. 1) gives straight lines with slopes near 2 as predicted by eq.(4); the results are in reasonable agreement with data obtained from the literature $^{[12]}$.

Furthermore, the extraction results were compared using solutions which separately contained DP-8R or LIX 860 reagents also diluted in Exxsol D100. Results were also summarized in table I. From these data it can be concluded that by using the reagents mixture the $\mathrm{pH}_{50}$ value for the extraction of cobalt and nickel is shifted to more acidic $\mathrm{pH}$ values if compared with the corresponding value obtained using the individual extractants. This shown the synergistic effect of the DP-8R/LIX 860 mixture on both metals extraction.

Also, and as mentioned above, the data obtained from these experiments matched well with data obtained from the literature ${ }^{[12]}$ and reflects that within the present extraction system:

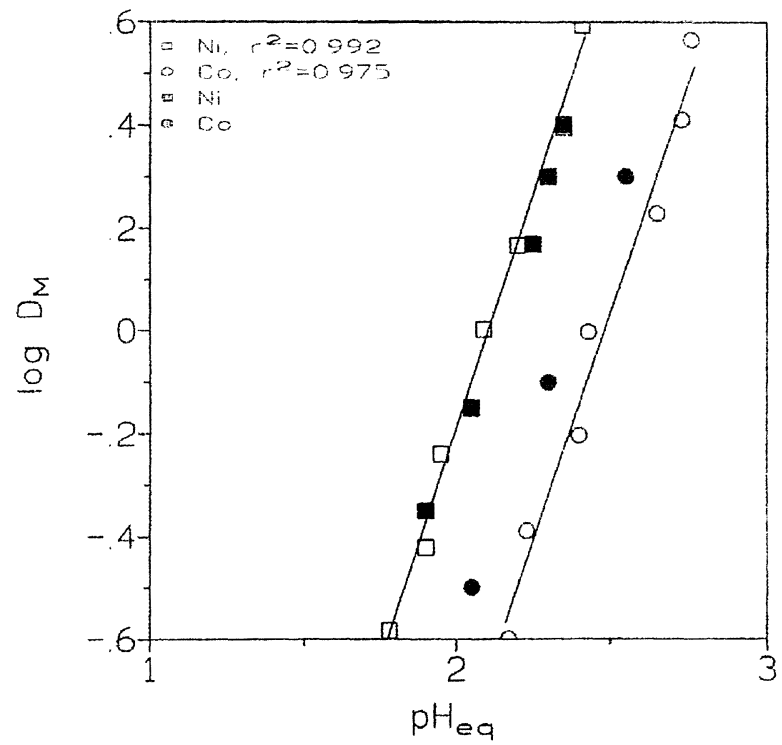

Figure 1. $\log D_{M}$ vs. $\mathrm{pH}$ plot for the extraction of cobalt(II) and nickel(II) by the mixture DP-8R/LIX $860(20 \% \mathrm{v} / \mathrm{v} / 20$ $\% \mathrm{v} / \mathrm{v})$ in Exxsol D100. Aqueous phase: $1 \mathrm{~g} / \mathrm{l} \mathrm{Ni}$ or $\mathrm{Co}$. Temperature: ' $20{ }^{\circ} \mathrm{C}$. Equilibration time: $15 \mathrm{~min}$. Unfilled points: this work. Filled points: data extrapolated from ${ }^{[12]}$.

Figura 1. Variación del $\log D_{M}$ frente al $\mathrm{pH}$ en la extracción de cobalto(III) y níquel(II) mediante la mezcla DP-8R/LIX 860 (20\% v/v/2 0\% v/v) en Exxsol D100. Fase acuosa: $1 \mathrm{~g} / \mathrm{l}$ Ni o Co. Temperatura: $20{ }^{\circ} \mathrm{C}$. Tiempo de equilibrado: 15 min. Puntos en blanco: este trabajo. Puntos en negro: datos tomados de ${ }^{[12]}$.

- the change of the organic diluent does not apparently affect the extraction of cobalt and nickel either by the extractants mixture or by each separate reagent.

Table I. Extraction of cobalt and nickel

Tabla I. Extracción de cobalto y níquel

\begin{tabular}{cc}
\hline Experimental variable & Remarks \\
\hline Equilibration time $^{\mathrm{a}}$ & $\mathrm{Ni}$ and Co extraction equilibria reached within 5 min \\
Equilibrium $\mathrm{pH}^{\mathrm{a}, \mathrm{b}}$ & Maximum Ni and Co extraction can be achieved at pH values near 3.0 \\
& $\mathrm{pH}_{50}$ for $\mathrm{Ni}: 2.09, \mathrm{pH}_{50}$ for $\mathrm{Co}: 2.43$ \\
& $\mathrm{pH}_{50}$ for $\mathrm{Ni}^{\mathrm{c}}: 3.63, \mathrm{pH}_{50}$ for $\mathrm{Co}^{\mathrm{c}}: 3.25$ \\
& $\mathrm{pH}_{50}$ for $\mathrm{Ni}^{\mathrm{d}}: 3.35, \mathrm{pH}_{50}$ for $\mathrm{Co}^{\mathrm{d}}: 4.26$ \\
\hline
\end{tabular}

\footnotetext{
Temperature: $20^{\circ} \mathrm{C}$ and $\mathrm{A} / \mathrm{O}$ phase ratio: $1: 1$.

${ }^{\mathrm{b}}$ Equilibration time: $15 \mathrm{~min}$.

Organic phase: ${ }^{\mathrm{c}} 20 \% \mathrm{v} / \mathrm{v}$ DP-8R in Exxsol D100, ${ }^{\mathrm{d}} 20 \% \mathrm{v} / \mathrm{v}$ LIX 860 in Exxsol D100.
}

$\mathrm{pH}_{50}$ is defined as the equilibrium $\mathrm{pH}$ value in which $50 \%$ metal extraction is reached. 
Solvent extraction with DP-8R/LIX 860 mixtures for the selective separation of cobalt and nickel

F.J. Alguacil

- the ionic strength also does not affect the extraction of both metals.

\subsection{Influence of temperature}

The influence of temperature on metal extraction was studied using an organic phase of $10 \% \mathrm{v} / \mathrm{v} \mathrm{DP}$. $8 \mathrm{R}$ and $10 \%$ v/v LIX 860 in Exxsol D100 and an aqueous phase of $1 \mathrm{~g} / \mathrm{l}$ each $\mathrm{Co}$ (II) and $\mathrm{Ni}(\mathrm{II})$ at $\mathrm{pH}$ 4.2 with 15 min contact time. Table II shows that temperature has a negligible effect on the extraction of both cobalt(II) and nickel(II).

\subsection{Influence of extractants mixture concentration in the organic phase}

In order to investigate the influence of the reagents concentrations on the extraction of both metals, each extractant concentration in the organic phase was varied between 2.5 and $20 \% \mathrm{v} / \mathrm{v}$ in Exxsol D100. Results of single stage extraction experiments carried out at different extractants mixture concentrations are shown in table III. Extraction of both cobalt(II) and nickel(II) increases with increasing extractants concentrations. However, nickel(II) is extracted in preference to cobalt(II) at all extractants mixture concentrations.

Having established the possibility of coextracting the two metals by the DP-8R/LIX 860 mixture, detailed studies were carried out to optimise conditions for the extraction and separation of cobalt and nickel from a typical aqueous solution containing $1 \mathrm{~g} / \mathrm{l}$ each cobalt(II) and nickel(II).

\subsection{Extraction isotherm}

To determine the number of stages required at a chosen volume phase ratio, an extraction isotherm

Table II. Influence of temperature on the extraction of Co(II) and $\mathrm{Ni}(I I)$ by the DP-8R mixture

Tabla II. Influencia de la temperatura sobre la extracción de Co(II) y Ni(II) mediante la mezcla DP-8R/LIX 860

\begin{tabular}{ccc}
\hline Temperature $\left({ }^{\circ} \mathrm{C}\right)$ & $\mathrm{Co}\left(\mathrm{g} / \mathrm{l}_{\text {org }}\right)$ & $\mathrm{Ni}\left(\mathrm{g} / \mathrm{l}_{\text {org }}\right)$ \\
\hline 20 & 0.22 & 0.41 \\
30 & 0.21 & 0.41 \\
40 & 0.22 & 0.42 \\
50 & 0.21 & 0.42 \\
60 & 0.23 & 0.43 \\
\hline
\end{tabular}

A/O phase ratio of 1
Table III. Influence of extractant mixture concentration on metal extraction

Tabla III. Influencia de la concentración de la mezcla de agentes de extracción sobre la extracción de los metales

\begin{tabular}{ccc}
\hline $\begin{array}{c}\text { Extractant concentration } \\
\text { DP-8R/LIX 860 }\end{array}$ & Co $\left(\mathbf{g} / \mathrm{I}_{\text {org }}\right)$ & $\mathrm{Ni}\left(\mathrm{g} / \mathrm{I}_{\text {org }}\right)$ \\
\hline $2.5 / 2.5$ & 0.06 & 0.16 \\
$5 / 5$ & 0.17 & 0.26 \\
$10 / 10$ & 0.21 & 0.44 \\
$20 / 20$ & 0.33 & 0.61 \\
\hline
\end{tabular}

Organic phase: DP-8R and LIX 860 in Exxsol D100. Aqueous phase: solution containing $1 \mathrm{~g} / \mathrm{l} \mathrm{Co}(\mathrm{II}), 1 \mathrm{~g} / \mathrm{l} \mathrm{Ni}(\mathrm{II})$ at $\mathrm{pH} 3.70$. Phase ratio: $1: 1$. Temperature: $20^{\circ} \mathrm{C}$. Equilibration time: $15 \mathrm{~min}$.

was generated with $20 \% \mathrm{v} / \mathrm{v}$ DP-8R and $20 \% \mathrm{v} / \mathrm{v}$ LIX 860 in Exxsol D100 and aqueous phase of $1 \mathrm{~g} / \mathrm{l}$ each 'of nickel(II) and cobalt(II) at initial $\mathrm{pH}$ of 5.5. Tests were carried out at $20^{\circ} \mathrm{C}$ and $15 \mathrm{~min}$ of equilibration time and shown that using an $\mathrm{A} / \mathrm{O}$ phase ratio of 0.55 four stages are needed to recover $90 \%(\mathrm{Co}(\mathrm{II})+\mathrm{Ni}(\mathrm{II}))$ from the feed solution and to obtain a load of $1 \mathrm{~g} / \mathrm{l}(\mathrm{Co}(\mathrm{II})+\mathrm{Ni}(\mathrm{II}))$ in the organic phase. Using an $\mathrm{A} / \mathrm{O}$ phase ratio of 1.33 , a load of $2 \mathrm{~g} / \mathrm{l}(\mathrm{Co}(\mathrm{II})+\mathrm{Ni}(\mathrm{II}))$ in the organic phase is obtained after five stages, thus yielding $75 \%$ $(\mathrm{Co}(\mathrm{II})+\mathrm{Ni}(\mathrm{II}))$ extraction.

\subsection{Metal stripping}

Figure 2 plotted the kinetics of metal stripping; it can be observed that the corresponding equilibrium is attained within 2 min (cobalt) or 10 min (nickel). Since the stripping of cobalt(II) is faster than that of nickel(II), their separation is possible by selective stripping of cobalt(II) in a short contact time and also by using diluted sulphuric acid solutions ${ }^{[12]}$. Near complete cobalt(II) stripping (>97\%) was achieved when the loaded organic phase is contacted (two stages) with $25 \mathrm{~g} / \mathrm{l}$ sulphuric acid solution and $1 \mathrm{~min}$ (other experimental conditions as in figure 2).

The cobalt-free organic phase was then subjected to stripping using an acidic solution containing $50 \mathrm{~g} / \mathrm{l}$ to remove the nickel. After two stripping stages at an $\mathrm{A} / \mathrm{O}$ volume phase ratio of $1: 1$, temperature $20^{\circ} \mathrm{C}$ and contact time of $5 \mathrm{~min}$, the yields were respectively $93.0 \%$ and $6.1 \%$, resulting in nickel stripping to the extent of $99.1 \%$. 


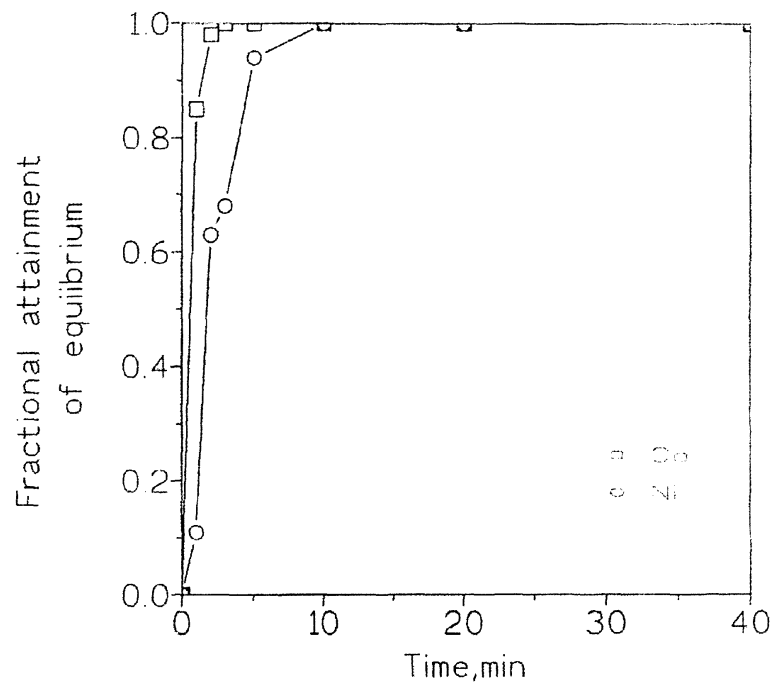

Figure 2. The kinetics of cobalt(II) and nickel(II) stripping. Organic phase: $20 \%$ v/v DP-8R and $20 \%$ v/v LIX 860 in Exxsol D100 loaded with $1 \mathrm{~g} / \mathrm{l}$ each of $\mathrm{Co}$ and $\mathrm{Ni}$. Aqueous phase: $25 \mathrm{~g} / \mathrm{l}$ sulphuric acid solution. Temperature: $20^{\circ} \mathrm{C}$. $\mathrm{A} / \mathrm{O}$ phase ratio of 1 .

Figura 2. Cinética de reextracción del metal. Fase orgánica: $20 \%$ v/v DP-8R y $20 \%$ v/v LIX 860 en Exxsol DI00 cargada con $1 \mathrm{~g} / \mathrm{l}$ de cada uno Co y Ni. Fase acuosa: disolución de $25 \mathrm{~g} / / \mathrm{H}_{2} \mathrm{SO}_{4}$. Temperatura: $20{ }^{\circ} \mathrm{C}$. Relación de fases $A / O$ igual a 1 .

\section{CONCLUSIONS}

The mixture DP-8R/LIX 860 extracts both cobalt(II) and nickel(II) from aqueous sulphate solutions in the $3.0 \mathrm{pH}$ range, however, extraction of both metals is sensitive to the equilibrium $\mathrm{pH}$ but is not dependent on temperature. Nickel is extracted preferably to cobalt(II) at various extractants mixture concentrations. From solution containing $2 \mathrm{~g} / \mathrm{l}$ (cobalt(II) and nickel(II)), both metals are almost quantitatively extracted in one stage $\left(\mathrm{pH}_{\mathrm{eq}} 3.0\right)$ using $20 \% \mathrm{v} / \mathrm{v} \mathrm{DP}-8 \mathrm{R}$ and $20 \%$ v/v LIX 860 in Exxsol D100.

Selective cobalt stripping from the loaded organic solution was achieved (batch operation) in two stages with $25 \mathrm{~g} / \mathrm{l} \mathrm{H}_{2} \mathrm{SO}_{4}$ aqueous phase and 1 min contact, cobalt(II) solution containing near $0.15 \mathrm{~g} / \mathrm{l}$ nickel.
Thus the objective of separating the two metals through co-extraction and selective stripping was accomplished. The cobalt-free organic solution was then used for nickel stripping with a solution of $50 \mathrm{~g} / \mathrm{l} \mathrm{H} \mathrm{SO}_{4}$.

\section{Acknowledgements}

To the CSIC (Spain) for support to carry out this work and to Mr.J.L.Bascones and Mr.M.López for technical assistance.

\section{REFERENCES}

[1] W.A. Rickelton, D.S. Flett and D.W. West, Solvent Extr. Ion Exch. 2 (1984) 815-838.

[2] D.S. FLETT, in Extractive Metallurgy of Nickel, A.R. Burkin (Ed.) SCI, London (1987).

[3] K.C. SOLE and J.B. HiSKEY, Hydrometallurgy 30 (1992) 345-365.

[4] B.K. TAIT, Hydrometallurgy 32 (1993) 365-372.

[5] N.B. Devi, K.C. Nathsarma and V. Chakravortty, Hydrometallurgy 49 (1998) 47-61.

[6] M. Cox, in Principles and Practices of Solvent Extraction, J. Rydberg, C. Musikas and G.R. Choppin (Eds.), Marcel Dekker, New York (1992).

[7] G.M. RitceY, in Solvent Extraction for the 21st Century, M.Cox, M.Hidalgo and M.Valiente (Eds.), SCI, London (2001).

[8] C.F. BAEs Jr, W.J. MCDOWEll and S.A. BRYAN, Solvent Extr. Ion Exch. 5 (1987) 1-28.

[9] G.M. Ritcey and A.W. Ashbrook, Solvent Extraction, Part I, Elsevier, Amsterdam (1984).

[10] F.J. Alguacil, AiChE J. 45 (1999) 2.136-2.141.

[11] M.E. CAmpdÉrRos and J. MARCHESE, Hydrometallurgy 61 (2001) 89-95.

[12] P. Zhang, T. Yokoyama, T.M. Suzuki and K. InOUe, Hydrometallurgy 61 (2001) 223-227.

[13] J. Szymanowski, Hydroxyoximes and Copper Hydrometallurgy, CRC Press, Boca Raton (1993).

[14] J.S. Preston, Hydrometallurgy 9 (1982) 115-133.

[15] P.R. Danesi, L. Reichley-Yinger, G. Mason, L. Kaplan, E.P. Horwitz and H. Diamond, Solvent Extr. Ion Exch. 3 (1985) 435-452. 